\title{
Diversity of black pepper plant (Piper nigrum) in Bangka Island (Indonesia) based on agro-morphological characters
}

\author{
GIGIH IBNU PRAYOGA`, ROPALIA, SITTI NURUL AINI, ERIES DYAH MUSTIKARINI, \\ YUNIAR ROSALIN \\ Department of Agrotechnology, Faculty of Agriculture, Fisheries and Biology, Universitas Bangka Belitung. Kampus Terpadu UBB, Gedung Semangat, \\ Jl. Raya Balunijuk, Merawang, Bangka 33172, Kepulauan Bangka Belitung, Indonesia. Tel.: +62-717-422145, `email: gigihibnuprayoga @ gmail.com
}

Manuscript received: 21 November 2019. Revision accepted: 20 January 2020.

\begin{abstract}
Prayoga GP, Aini SN, Mustikarini, ED, Rosalin Y. 2020. Diversity of black pepper plant (Piper nigrum L.) in Bangka Island (Indonesia) based on agro-morphological characters. Biodiversitas 21: 652-660. Black pepper (Piper nigrum L.) production in Bangka Belitung Islands Province continued to decrease in 2014-2017. Efforts to increase black pepper production was carried out by providing superior varieties that began with an increase in the genetic diversity of black pepper plants. Increasing the genetic diversity of black pepper can be done through black pepper germplasm exploration activities followed by characterization. The research aimed to obtain the agro-morphological characteristics of black pepper plants in Bangka island. Exploration was carried out by survey method in four regencies in Bangka Island. The research method used a survey method with convenience sampling technique. Observation of agromorphological characters was carried out in accordance with the descriptor for black pepper from IPGRI (1995). The results of exploration of black pepper plants in Bangka Island have found 9 accessions of black pepper plants, consisting of 5 cultivars were Lampung Daun Lebar (LDL), Lampung Daun Kecil (LDK), Chunuk, and Jambi and 4 landraces namely Bogor, Peremis, Keriwil, and Merapin Daun Kecil (MDK). There were morphological differences in 9 accessions of black pepper plants, namely leaf lamina shape, leaf vein, leaf margin, lateral branch habit, leaf base shape, ripe fruit color, hanging vines, ground vines, and stem shape. Agromorphological relationship of 9 accessions of black pepper plants can be divided into 5 clusters at a 50\% similarity level. Based on this study, black pepper breeding program on Bangka Island could be done accessions of Peremis, Bogor, Nyelungkup, and Jambi as genetic sources. Furthermore, selection would be better to use length of petiole, length of stem segment, fruit size, percentage of perfect fruit, weight of 1000 fruits, and the weight of 1000 dried seeds as the selection criteria.
\end{abstract}

Keywords: Bangka, black pepper, relationship, variability

\section{INTRODUCTION}

Black pepper (Piper nigrum L.) is an important spice plant that cannot be replaced by other spices, contributors to the country's foreign exchange, employment providers, and domestic industrial raw materials. Black pepper is also famous as the king of spices due to its pungent quality (Srinivasan 2007). One of the black pepper producing regions in Indonesia is the Kepulauan Bangka Belitung Province (Yudiyanto et al. 2014), and its product was well known in the world market as Muntok White Pepper (Ravindran 2000) with Geographical indications: Muntok White Pepper (Direktorat Jenderal Kekayaan Intelektual 2019). Black Pepper productivity in Bangka Belitung has declined from 2014-2018, respectively 1.53, 1.26, 1.24, 1.20, and 1.17 tons/ha/year (BPS-Statistics of Kepulauan Bangka Belitung Province 2019). The decline of black pepper productivity in Bangka Belitung was influenced by various factors, including decreasing land production by the exploitation of smallholder plantations with limited scale of business and limited capital (Listyati et al. 2012), as well as disruption of plant organisms, especially stem rot disease (Wahyuno et al. 2010). Therefore, based on these conditions, efforts are needed to increase pepper production and productivity.
The first step in efforts to increase black pepper production is by providing superior varieties. At present, there are only ten varieties of black pepper in Indonesia, namely Natar 1, Natar 2, Petaling 1, Petaling 2, Lampung Daun Kecil, Bengkayang, Chunuk, Ciinten, Malonan-1, and Nyelungkup which were released in 1988-2018 (Pusat Perlindungan Varietas Tanaman dan Perizinan Pertanian 2019). Some of the varieties only have tolerant of stem rot disease (Lampung Daun Kecil, Bengkayang and Chunuk) and tolerant against yellowing disease (Bengkayang), but there are no varieties that are resistant to both of main diseases of the black pepper. Disease epidemics can narrow genetic diversity which may decimate population (Singh et al. 2014). Plant production tends to depend on genetic diversity. Substantial losses in production have resulted from a narrow genetic base (Cooper et al. 2001). Increasing the genetic diversity of black pepper is needed as a source of genes in the development of superior varieties of black pepper.

Increasing the genetic diversity of black pepper can be done through plant breeding programs. Breeding activities begin with germplasm collection as a source of diversity and several other stages of activity up to the release of plant varieties (Carsono 2008). Aside from the cultivation of black pepper germplasm, the source of genetic diversity for the improvement of black pepper varieties can also be 
obtained from local, native and wild black pepper. In addition, increasing crop productivity in an area can be done by exploring genetic diversity of germplasm (Tshilenge-Lukanda 2012). Therefore, the position and role of germplasm are needed in an effort to increase the production of black pepper plants through the use of superior genes contained in germplasm accession.

The next activity after exploration is characterization. The stages of plant breeding begin with collecting germplasm, identification, and characterization, increasing diversity, selection, testing and evaluation, and ending with the release of varieties (Carsono 2008). Characterization is important because each germplasm will show different characteristics according to the environment. The availability of genotypes that have specific characteristics will have a major impact on the effectiveness and acceleration of plant breeding programs in producing superior varieties that have economic value. Bangka Island is dominated by acidic land and ultisols soil (Santi et al. 2018) allows the discovery of local black pepper germplasm that has the potential to be developed into national and regional-specific superior varieties. The research aims to obtain the black pepper plant on Bangka island and its agro-morphological characteristics. The information obtained can later be used as a basis for assembling national superior varieties of black pepper and region-specific varieties in order to increase national black pepper production.

\section{MATERIALS AND METHODS}

\section{Plant materials}

The research was conducted in December 2018 - May 2019 on Bangka Island. Exploration was carried out in four regencies (Bangka, Bangka Tengah, Bangka Barat, and Bangka Selatan), Kepulauan Bangka Belitung Province, Indonesia (Table 1 and Figure 1), especially black pepper planting centers, traditional production areas, and remote areas. During the exploration, plant passport data recording was also carried out, namely: accession number, accession name, and village. Black pepper plants that were observed were plants that had been planted in the same location for more than five years, with the age of the plants observed at least three years, to ensure that plants are local plants that have been cultivated for generations.

Table 1. Location of black pepper studied in Bangka Island, Bangka Belitung Province, Indonesia

\begin{tabular}{lll}
\hline District & Sub-district & Village \\
\hline Bangka & Mendo Barat & Paya Benua \\
& Mendo Barat & Zed \\
Bangka Tengah & Pangkalan Baru & Air Mesu \\
Bangka Selatan & Air Gegas & Nyelanding \\
Bangka Barat & Simpang Teritip & Kundi \\
& Simpang Teritip & Air Menduyung \\
\hline
\end{tabular}

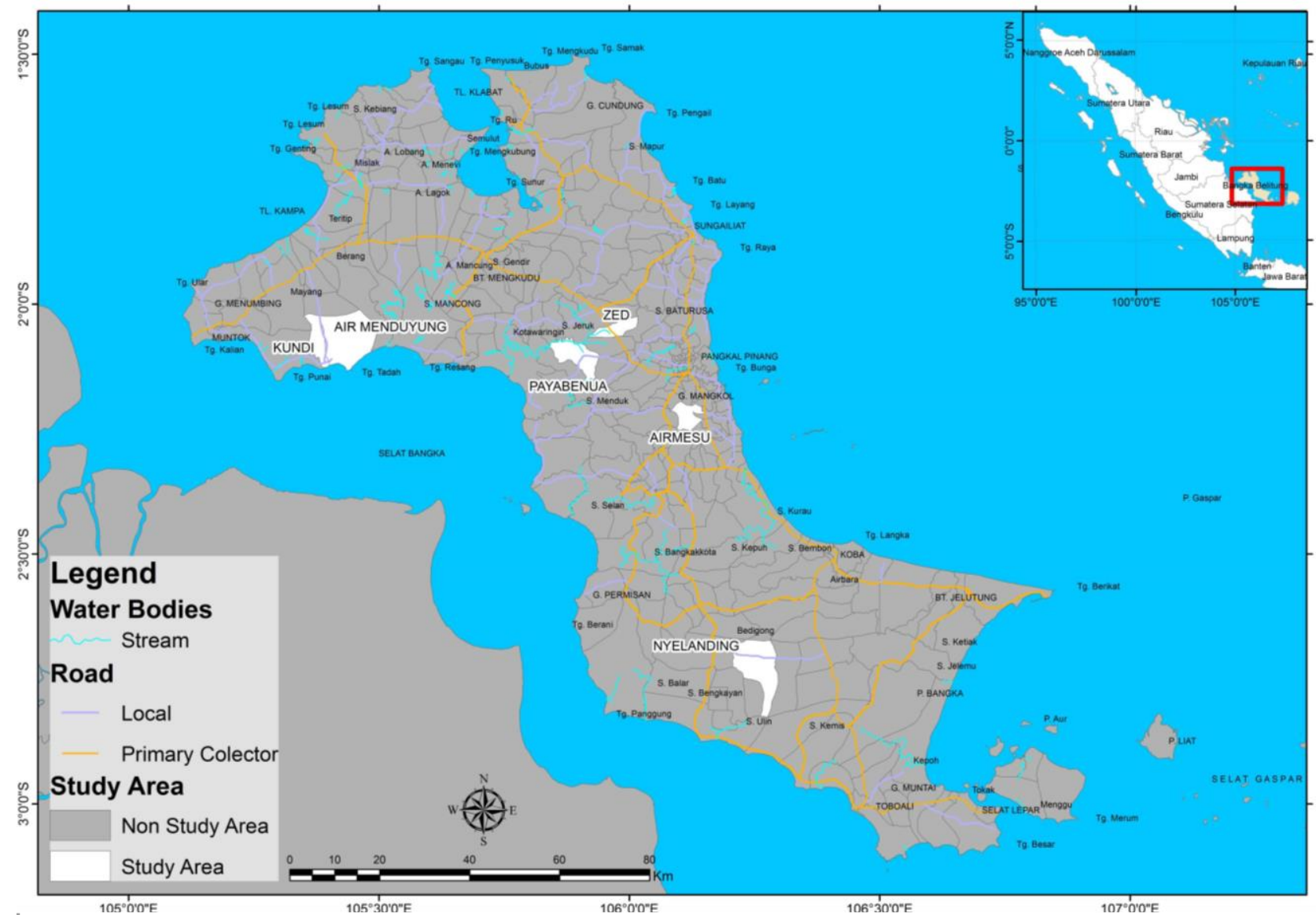

Figure 1. Location of black pepper studied in Bangka Island, Bangka Belitung Province, Indonesia 


\section{Procedure}

The research method used the survey method. Sampling was done by using convinience sampling technique. Convenience sampling is one of the sampling methods based on the probabilities put forward in several practical criteria such as easy accessibility, geographical proximity, or time schedule in accordance with the research objectives (Etikan et al. 2016), on the account that the condition of the plantation was considered suitable as a data source. A minimum of 5 plant samples was taken from each location to meet the criteria of $10 \%$ of the population sample. Each plant sample was marked and the agro-morphological characters were observed. Observation of agromorphological characters was carried out in accordance with the Descriptor for Black Pepper (Piper nigrum L.) (IPGRI 1995). The characters observed were leaf lamina shape, leaf surface, leaf vein, leaf margin, lateral branch habit, leaf base shape, leaf tip, leaf color, flowering nature, fruit shape, young fruit color, ripe fruit color, young stem color, ripe stem color, hanging vine, ground vine, stem shape, plant growth habit, length of petiole, length of stem segment, age of flowering, fruit size, fruit weight per spike, percentage of perfect fruit, weight of 1000 fruit, and weight of 1000 seeds.

\section{Data analysis}

The data obtained was divided into qualitative and quantitative data types. Analysis of qualitative data was done by descriptive method. Quantitative data were used to determine the phenotypic variability value of various characters of black pepper germplasm. Phenotypic coefficient of variation (PCV) was calculated by using the formula according to Kearsey and Pooni (1996) thus:

$$
\% \mathrm{PCV}=\left(\left(\sigma_{\mathrm{p}}^{2}\right)^{1 / 2}(\overline{\boldsymbol{X}})^{-1}\right) 100 \% \text { where } \sigma_{\mathrm{p}}^{2}=\mathrm{N}^{-1}\left(\sum[\mathrm{xi}-\bar{X}]^{2}\right)
$$

Where, $\bar{x}=$ grand mean of the character, $\mathrm{xi}=$ value of character-i, $\mu=$ mean of population, $\mathrm{N}=$ total of plant observed, $\sigma_{p}^{2}=$ phenotypic variance.

Morphological relationship analysis among black pepper germplasm was also carried out based on the UPGMA (Unweighted Pair Group Method with Arithmetic Mean) using Numerical Taxonomy and Multivariate Analysis System (NTSYS-PC) version 2.20 software.

\section{RESULTS AND DISCUSSION}

\section{Exploration of black pepper in Bangka Island}

Exploration of black pepper plants in Bangka Island has found 9 accessions, consisting of 5 cultivars and 4 landraces. The cultivars that were planted in Bangka Island were Lampung Daun Lebar (LDL), Lampung Daun Kecil (LDK), Chunuk, and Jambi varieties. Exploration results also found 4 landraces of black pepper, namely Bogor, Peremis, Keriwil, and Merapin Daun Kecil (MDK). Accessions of LDL, LDK, Chunuk, Jambi, Bogor, and MDK were reported as cultivated plants in Bangka island (Panggabean, 2016; Pusat Penelitian dan Pengembangan Perkebunan 2015), but Bogor, Peremis and Keriwil accessions have never been studied before. Black pepper's location and passport data from exploration results are shown in Table 2.

\section{Agro-morphological characters of black pepper in Bangka Island}

Agro-Morphological characters for 9 accessions of black pepper can be seen in Table 3. Morphological characters of 9 black pepper plants observed had some similarities, namely the leaf vein (campylodromous), leaf tips (pointed), leaf color (dark green), young stem color (dark green), ripe stem color (green-brown), young fruit color (dark green), flowering nature (seasonal), fruit shape (round), and climbing growth habit type. Morphological differences in 9 black pepper plants can be seen from several parameters, namely the character of leaf lamina shape, leaf surface, leaf margin, lateral branch habit, leaf base shape, fruit shape, ripe fruit color, hanging vines, ground vines and stem shape.

The nine accessions of black pepper have the same type of leaf vein, which is campylodromous (Figure 1). Campylodromous venation is which several primary veins run in prominent, recurved arches at the base, curving upward to converge at the leaf apex (Simpson 2011). The same type of leaf vein is also found in Ciinten variety (Bermawie 2019). Variations in the shape of black pepper leaves found were ovate-elliptic, ovate-lanceolate and elliptic-lanceolate (Figure 3). Black pepper plants had 2 variations of leaf base shape, namely Round and acute (Figure 4).

Table 2. Passport data of 5 black pepper cultivars and 4 local black pepper accessions explored in Bangka Island, Indonesia

\begin{tabular}{llll}
\hline Accessions & Code & Cultivar/Landrace & Village \\
\hline Lampung Daun Lebar & LDL & Cultivar & Payabenua and Zed. \\
Lampung Daun Kecil & LDK & Cultivar & Air Mesu and Zed. \\
Chunuk & Cnk & Cultivar & Payabenua and Air Mesu. \\
Jambi & Jmb & Cultivar & Nyelanding and Payabenua. \\
Nyelungkup & $\mathrm{Nye}$ & Cultivar & Zed, Air Mesu, and Nyelanding. \\
Bogor & $\mathrm{Bg}$ & Landrace & Air Mesu and Payabenua. \\
Keriwil & $\mathrm{Krl}$ & Landrace & Zed \\
Peremis & $\mathrm{Pr}$ & Landrace & Payabenua \\
Merapin Daun Kecil & MDK & Landrace & Zed, Payabenua, Air Menduyung, and Kundi \\
\hline
\end{tabular}


Table 3. Agro-morphological characters of 9 accessions black peppers in Bangka Island, Indonesia

\begin{tabular}{|c|c|c|c|c|c|c|c|c|c|}
\hline \multirow[b]{2}{*}{ Characters } & \multicolumn{4}{|c|}{ Landraces } & \multicolumn{5}{|c|}{ Cultivars } \\
\hline & Bogor & Keriwil & Peremis & $\begin{array}{c}\text { Merapin Daun } \\
\text { Kecil } \\
\end{array}$ & $\begin{array}{c}\text { Lampung daun } \\
\text { Lebar }\end{array}$ & $\begin{array}{c}\text { Lampung Daun } \\
\text { kecil }\end{array}$ & Chunuk & Jambi & Nyelungkup \\
\hline Leaf lamina shape & Eliptic-lanceolate & Ovate-Lanceolate & Ovate-Lanceolate & Eliptic-lanceolate & Ovate-elliptic & Ovate-elliptic & Ovate-Lanceolate & Ovate-elliptic & Eliptic-lanceolate \\
\hline Leaf Surface & Smooth-glossy & Smooth & Smooth & Smooth & Smooth & Smooth & Smoot & Smooth & Smooth-Glossy \\
\hline Leaf Vein & Campylodromous & Campylodromous & Campylodromous & Campylodromous & Campylodromous & Campylodromous & Campylodromous & Campylodromous & Campylodromous \\
\hline Leaf margin & Wavy (repand) & Even (entire) & Even (entire) & Wavy (repand) & Even (entire) & Even (entire) & Even (entire) & Even (entire) & Even (entire) \\
\hline Lateral branch habit & Hanging & Erect & Erect & Hanging & Horizontal & Horizontal & Hanging & Horizontal & Erect \\
\hline Leaf Base Shape & Round & Acute & Acute & Round & Round & Round & Round & Round & Round \\
\hline Leaf tip & Acute & Acute & Acute & Acute & Acute & Acute & Acute & Acute & Acute \\
\hline Leaf color & Dark green & Dark green & Dark green & Dark green & Dark green & Dark green & Dark green & Dark green & Dark green \\
\hline Flowering nature & Seasonal & Seasonal & Seasonal & Seasonal & Seasonal & Seasonal & Seasonal & Seasonal & Seasonal \\
\hline Fruit Shape & Round & Round & Round & Round & Round & Ovate & Round & Round & Round \\
\hline Young Fruit Color & Green & Green & Green & Green & Green & Green & Green & Green & Green \\
\hline Ripe Fruit Color & Orange & Orange to red & Orange to red & Orange & Orange to red & Orange to red & Orange & Orange & Orange to red \\
\hline Young Stem Color & Dark green & Dark green & Dark green & Dark green & Dark green & Dark green & Dark green & Dark green & Dark green \\
\hline Ripe Stem Color & Greenish brown & Greenish brown & Greenish brown & Greenish brown & Greenish brown & Greenish brown & Greenish brown & Greenish brown & Greenish brown \\
\hline Hanging Vine & None & None & Moderate & None & Few & Moderate & Few & Few & Few \\
\hline Ground Vine & None & None & Few & None & Few & Few & Few & Moderate & None \\
\hline Stem Shape & Flat & Flat & Intermediate & Flat & Round & Round & Round & Flat & Flat \\
\hline Plant Growth habit & Climbing & Climbing & Climbing & Climbing & Climbing & Climbing & Climbing & Climbing & Climbing \\
\hline Length of Petiole $(\mathrm{cm})$ & 1.2 & 1.8 & 1.6 & 1.3 & 1.7 & 1.9 & 1.6 & 1.8 & 1.6 \\
\hline Length of Stem Segment $(\mathrm{cm})$ & 6.0 & 4.0 & 5.0 & 3.5 & 3.9 & 4.4 & 6.0 & 5.4 & 4.5 \\
\hline Age of Flowering (month) & 8 & 7 & 9 & 8 & 9 & 7 & 8 & 9 & 8 \\
\hline Fruit Size (mm) & 6.2 & 5.7 & 6.4 & 6.5 & 6.1 & 6.4 & 6.2 & 4.0 & 4.9 \\
\hline Fruit Weight Per Spike (g) & 7.5 & 8.3 & 8.0 & 5.3 & 11.5 & 9.2 & 4.5 & 11.2 & 7.0 \\
\hline Percentage of Perfect Fruit (\%) & 83.1 & 62.3 & 70.8 & 68.5 & 87.9 & 90.7 & 81.4 & 64.5 & 60.7 \\
\hline Weight of 1000 fruit $(\mathrm{g})$ & 125.8 & 89.98 & 150.08 & 125.8 & 129.43 & 131.2 & 144.93 & 174.56 & 140.55 \\
\hline Weight of 1000 dried seeds (g) & 39.00 & 27.67 & 40.91 & 35.8 & 40.42 & 38.35 & 46.00 & 52.52 & 52.61 \\
\hline
\end{tabular}




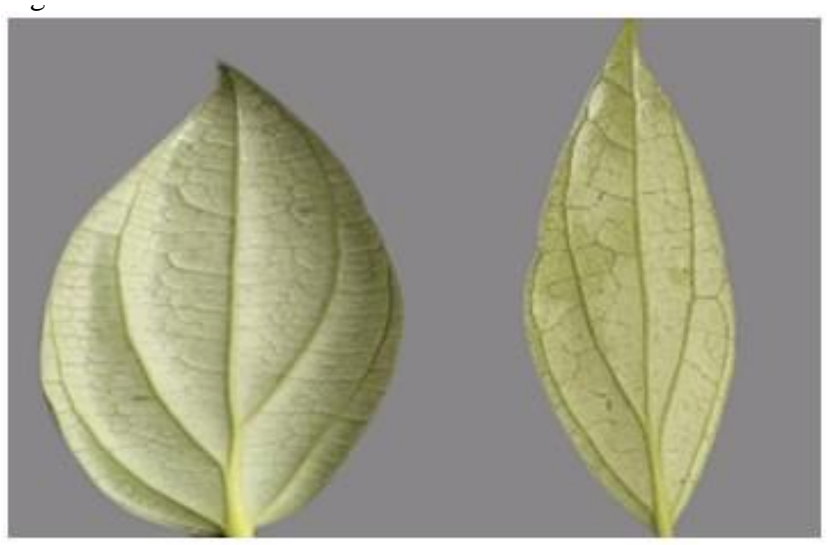

Figure 2. Leaf venation campylodromous

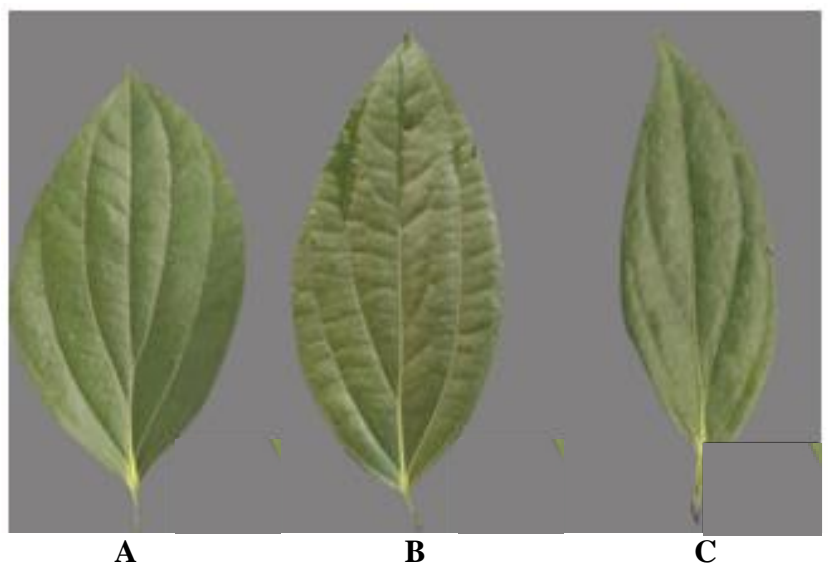

Figure 3. Variation in the leaf lamina shape; A. Ovate-elliptic, B. Ovate- lanceolate, and C. Eliptic-lanceolate

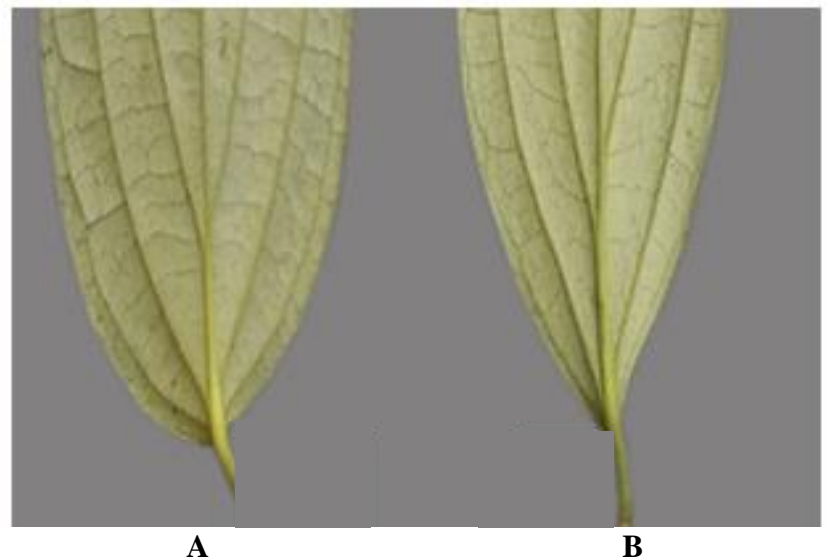

Figure 4. Variation in the shape of the black pepper leaf base shape; A. Round, and B. Acute

The shape of leaf margin explored had 2 variations, namely even and wavy (Figure 5). Based on Pusat Perlindungan Varietas Tanaman dan Perizinan Pertanian (2019), black pepper varieties in Indonesia have mostly ovate leaf lamina shape, round leaf base shape, and even type of leaf margin (Table 4). Bermawie (2019) also reported that Ciinten variety had an ovate-lanceolate leaf lamina shape, acute leaf tip, and cordate type of leaf base shape.

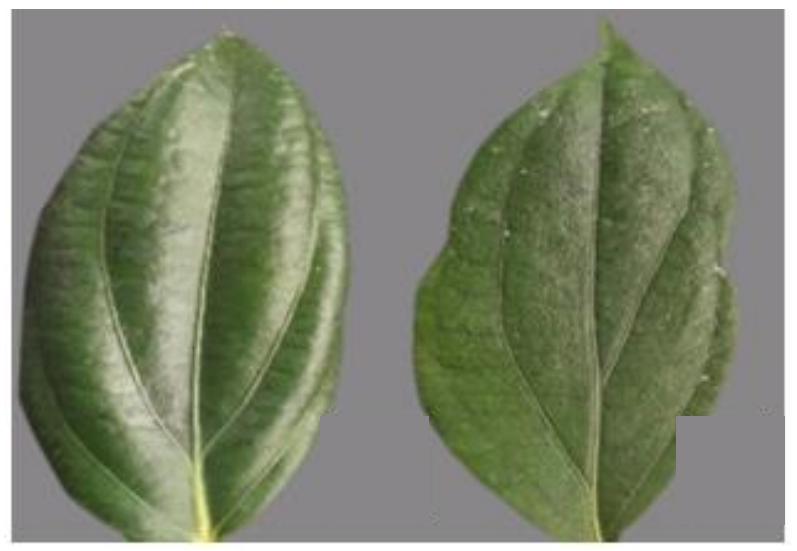

A

B

Figure 5. Variation in the shape of the black pepper leaf margin; A. Even, and B. Wavy.

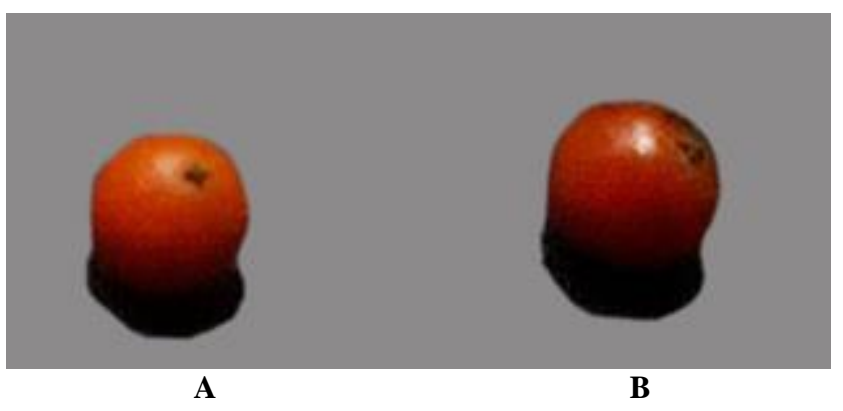

Figure 8. Variation of Ripe Fruit Color; A. Orange, B. Red to Orange

The types of lateral branch habit observed had three types namely erect, horizontal and hanging (Figure 6). Most lateral branch habit of black pepper varieties in Indonesia are erect (Pusat Perlindungan Varietas Tanaman dan Perizinan Pertanian 2019). Stem shape on 9 black pepper plants obtained 3 types, namely round, flat, and slightly flat (Figure 7). There were 2 kinds of ripe fruit color, namely orange and orange to red (Figure 8). Almost all the accessions of black pepper have a round fruit shape, except for the Lampung Daun Kecil variety which has the ovate fruit shape. Orange ripe fruit and round ripe fruit is also found in Ciinten (Bermawie 2019), and Malonan 1 varieties (Pusat Perlindungan Varietas Tanaman dan Perizinan Pertanian 2019).

Relationship analysis of black pepper plants in Bangka Island based on agro-morphological characters is displayed as dendrogram (Figure 9). The dendrogram shows 5 clusters at a coefficient level of 0.50 or $50 \%$ similarity in characteristics. Lampung Daun Lebar (LDL) and Lampung Daun Kecil (LDK) varieties are in one cluster. Chunuk and Nyelungkup are in the same cluster as Bogor and Merapin Daun Kecil (MDK). Black pepper accessions of Jambi, Peremis, and Keriwil are each located in a different cluster. Black pepper plants that had the highest level of characteristic similarity, which was $77 \%$, were accessions of Bogor and Merapin Daun Kecil. 


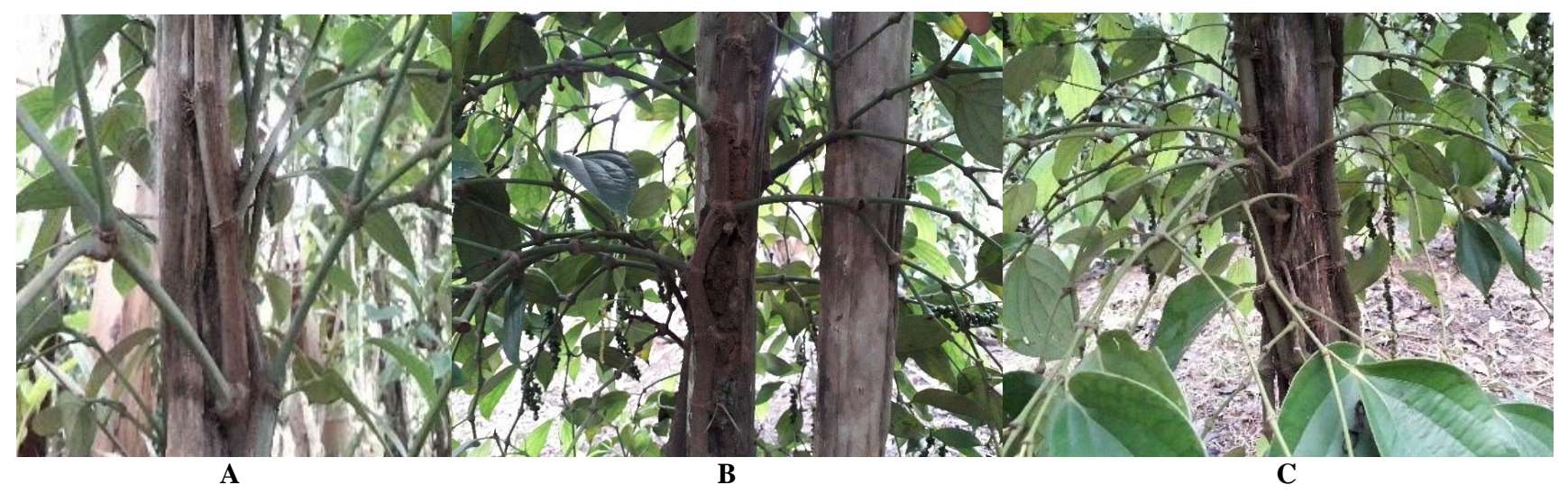

Figure 6. Lateral branch habit: A. Erect, B. Horizontal, CHanging

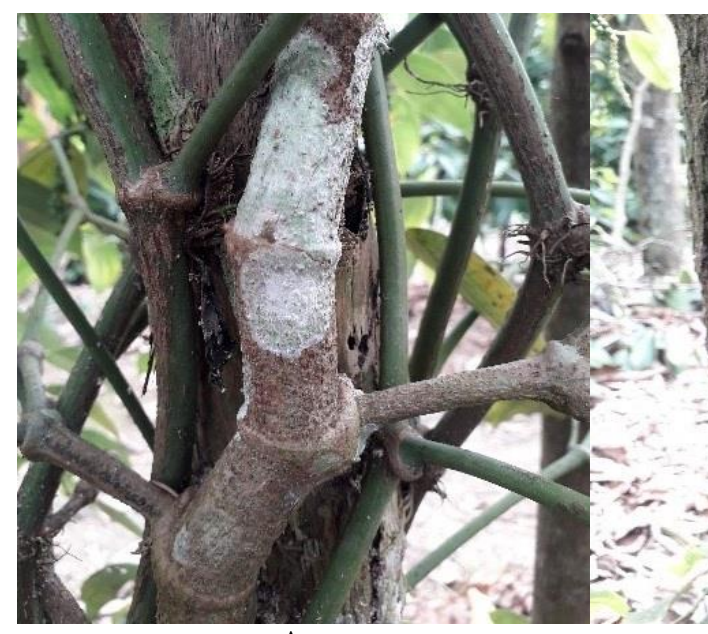

A

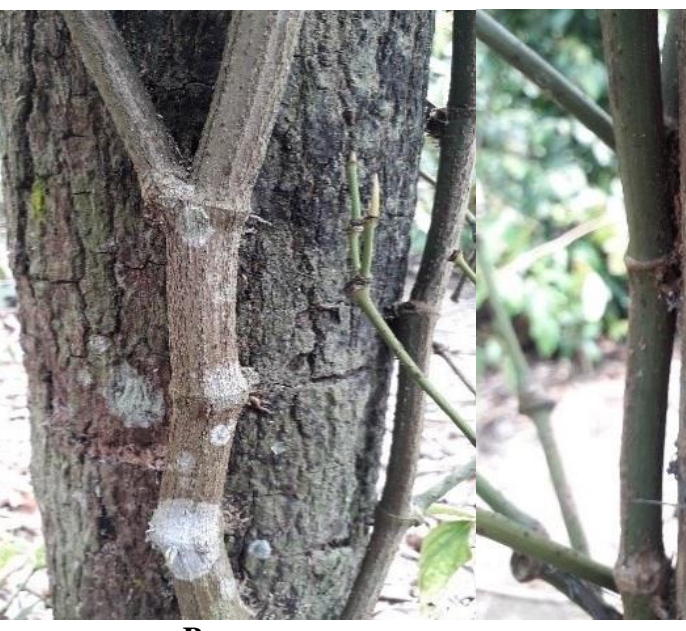

B

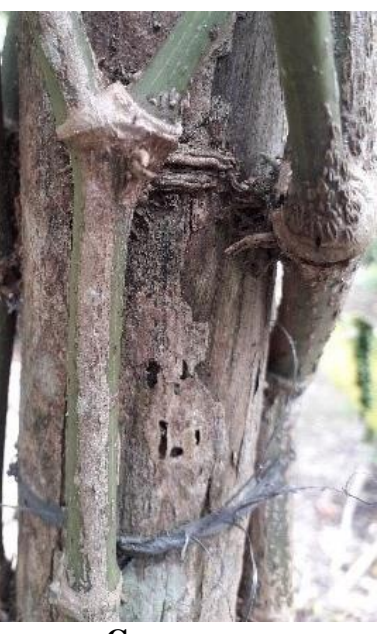

C

Figure 7. Stem shape: A. Round, B. Slightly flat, C. Flat

Relationship analysis is used to classify objects based on the similarity of certain characteristics. For evolving high yielding varieties of any crop, knowledge on the relationship between characters is essential (Preethy et al. 2018). The dendrogram drawing of a 0.50 or $50 \%$ threshold line is divided into five clusters. The dendrogram results also showed a close relationship between accession Bogor and Merapin Daun Kecil (MDK), which was 0.77 or $77 \%$. Goncalves et al. (2013) state the similarity distance with a coefficient of $75 \%$ or more can be said that the accession has a high similarity or low diversity. These similarities can be due to changes in phenotypic traits. Populations in the same ecological conditions, in the long-term evolutionary process, form the same adaptation matrix to produce phenotypic similarities (Sun et al. 2019). Close relationship between the accession of Bogor and Merapin Daun Kecil allegedly because these two varieties originated from the same parent. The morphological difference between Bogor pepper and merapin is only the size of the leaves, which is the size of Bogor pepper leaves is bigger than merapin
(Pusat Penelitian dan Pengembangan Perkebunan 2015). Some genetics originate from the same parent but are scattered to different places so that they are given different names and are cultivated from generation to generation without knowing their history and genealogy.

The criteria for variability of agro-morphological characters in 9 black pepper plants are listed in Table 5. The variability criteria were divided into 4 criteria: narrow, quite narrow, quite wide, and wide. The determination of the criteria for each character was based on the value of the phenotypic coefficient of variation (PCV). Based on Effendy (2018), the highest PCV value was determined as a $100 \%$ variation. The highest PCV value was owned by the character of length of petiole, namely $79 \%$, so the PCV value range for variability criteria was $0-20 \%=$ narrow, 20 $40 \%=$ quite narrow, $40-60 \%=$ quite wide, and $60-80 \%=$ wide. The character of length of petiole had wide phenotypic variability criteria. The characters that had phenotypic variability criteria which were quite wide, namely the length of stem segment and fruit size. The 
character with phenotypic variability criteria of quite narrow was the age of flowering and the average fruit weight. Percentage of fruits per spike, weight of 1000 fruit, and weight of 1000 dried seeds had narrow phenotypic variability criteria.

The agro-morphological character of black pepper in Bangka Island has phenotypic variability or phenotypic diversity in the form of wide, quite wide, quite narrow, and narrow. The phenotypic variances were very far from each other shows the high influence of environment on black pepper traits (Preethy et al. 2018). The value of variability is the important component to measure before determining the method and time to perform further selection (Mustikarini et al. 2019). Characters that have a wide and quite wide phenotypic diversity can be utilized for developing superior varieties of black pepper. Goncalves et al. (2013) state that although the phenotype diversity value may not be inherited, if it has wide character, it will be the right start in an effective selection process. Conversely, narrow variability indicated that the individuals were in a relatively homogenous population so that the selection which is based on the character will be less effective (Waqar-Ul-Haq et al. 2008). Selection will be effective if done on characters whose variability is quite wide and wide. Based on variability results, the black pepper breeding program on Bangka Island can be done using length of petiole, length of stem segment, and fruit size. According to Preethy et al. (2018) selection program based on agronomic characters, such as dry weight of berries, would be better than selection based on size of berries and number of berries/spike in black pepper. Therefore, the selection criteria for black pepper breeding programs would be better if the percentage of perfect fruit, weight of 1000 fruits, and the weight of 1000 dried seeds were also used for selection. Furthermore, developing black pepper superior varieties could be done using accessions of Peremis, Bogor, Nyelungkup, and Jambi as genetic sources for breeding program.

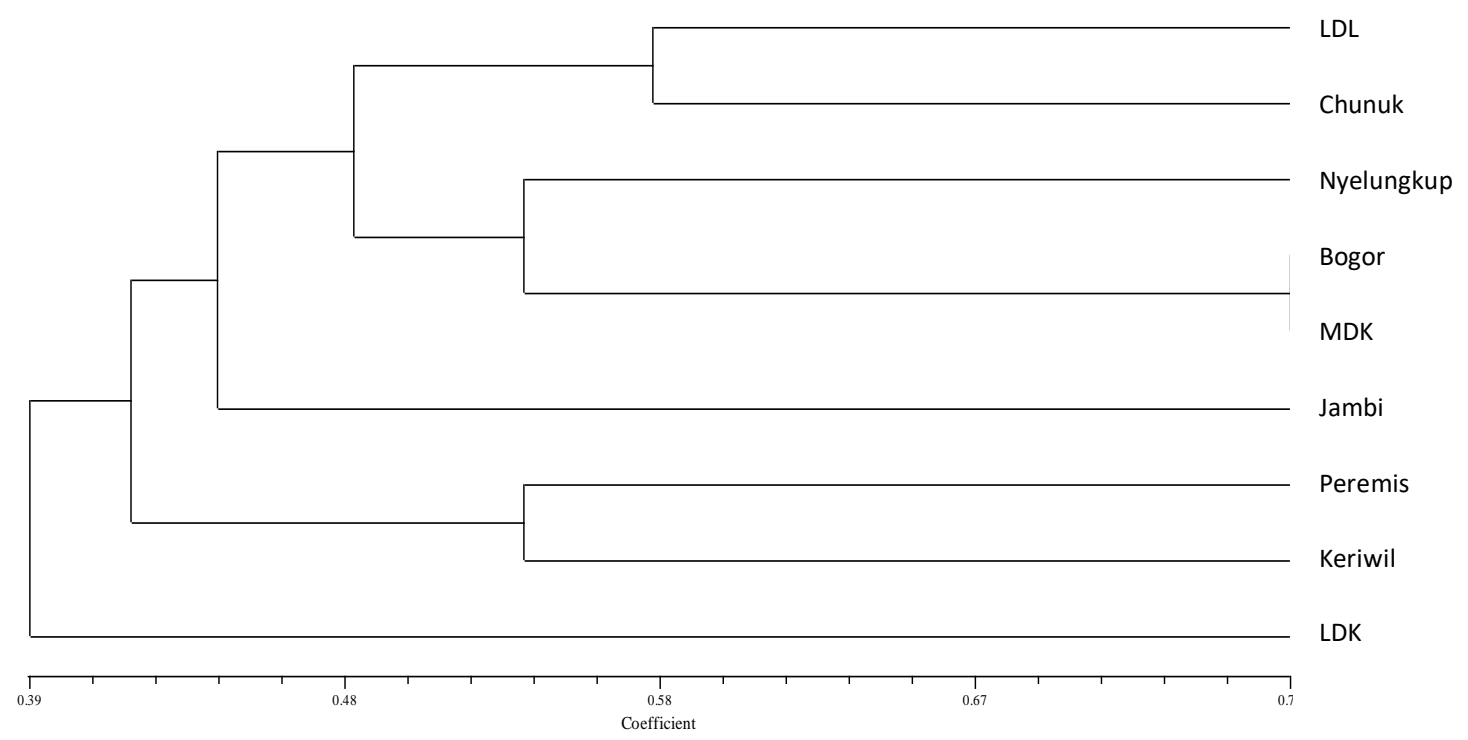

Figure 9. Dendrogram on the relationship of black pepper plants based on agro-morphological characters

Table 5. Variability of Agro-Morphological characters of black pepper plants in Bangka Island, Indonesia

\begin{tabular}{lcccl}
\hline Quantitative character & $\overline{\boldsymbol{x}}$ & $\boldsymbol{\sigma}_{p}^{2}$ & PCV (\%) & Criteria \\
\hline Length of petiole (cm) & 1.6 & 1.611 & 79.328 & Wide \\
Length of stem segment (cm) & 4.7 & 4.744 & 46.342 & Quite Wide \\
Age of flowering (month) & 8 & 8.111 & 35.600 & Quite Narrow \\
Fruit size (mm) & 5.8 & 5.822 & 41.601 & Quite Wide \\
Fruit weight per spike (g) & 8.0 & 8.044 & 35.452 & Quite Narrow \\
Percentage of perfect fruit (\%) & 74.4 & 74.426 & 11.595 & Narrow \\
Weight of 1000 fruit (g) & 134.7 & 134.703 & 8.616 & Narrow \\
Weight of 1000 dried seeds (g) & 41.5 & 41.476 & 15.519 & Narrow \\
\hline
\end{tabular}

Note: ${ }^{\bar{x}}=$ average, ${ }^{2}{ }_{p}^{2}=$ phenotype variance, $\mathrm{PCV}=$ phenotypic coefficient of variation 
Table 4. Characteristics comparison between Bangka Island, Indonesia black pepper and black pepper released varieties

\begin{tabular}{|c|c|c|c|c|c|c|c|}
\hline \multirow[b]{2}{*}{ Characters } & \multirow[b]{2}{*}{ Bangka black pepper from exploration } & \multicolumn{6}{|c|}{ Released varieties } \\
\hline & & Petaling 1 & Petaling 2 & Natar 1 & Natar 2 & Ciinten & Malonan 1 \\
\hline Leaf Lamina Shape & $\begin{array}{l}\text { Ovate-lanceolate, elliptic-lanceolate, } \\
\text { ovate-elliptic }\end{array}$ & Ovate & Ovate & Ovate & Ovate & Ovate & Elliptic \\
\hline Leaf Surface & Smooth and smooth-glossy & Smooth-glossy & Smooth-glossy & Smooth-glossy & - & - & smooth \\
\hline Leaf Vein & Campylodromous & Pinnate & Pinnate & Pinnate & Pinnate & Campylodromous & pinnate \\
\hline Leaf margin & Even and wavy & - & - & - & Wavy & Even & Even \\
\hline lateral branch habit & Erect, hanging, horizontal & Erect & - & Erect & Erect & - & - \\
\hline Leaf Base Shape & Round and Acute & Round to Oblique & Acute to oblique & Round & Round to oblique & - & Round \\
\hline Leaf tip & Acute & Acute & Acute & Acute & Acute & Acute & Acute \\
\hline Leaf color & Dark green & Dark green & Dark green & Dark green & Dark green & Dark green & Green \\
\hline Flowering nature & Seasonal & Seasonal & Seasonal & Seasonal & Seasonal & - & all year round \\
\hline Fruit Shape & Round and ovate & Round & Round & Round & Round & Round & - \\
\hline Young Fruit Color & Green & Green & Green & Green & Light green & Green & Green \\
\hline Ripe Fruit Color & Orange and Orange to red & Orange to red & Orange to red & Orange to red & Orange to red & orange & Orange \\
\hline Young Stem Color & Dark green & - & greenish purple & greenish purple & greenish purple & Green & Green \\
\hline Ripe Stem Color & Greenish brown & - & - & - & - & Brown & Green \\
\hline Hanging Vine & Few and moderate & Many & Few & Many & Few & Few & Few \\
\hline Ground Vine & Few and moderate & Many & Few & Many & Few & Few & Few \\
\hline Stem Shape & Flat, intermediate, round & Flat & Flat & Flat & Flat & - & Round \\
\hline Plant Growth habit & Climbing & Climbing & Climbing & - & - & - & - \\
\hline Length of Petiole $(\mathrm{cm})$ & $1.2-1.9$ & 2.1 & 2.1 & 2 & 2.5 & - & - \\
\hline Length of Stem Segment $(\mathrm{cm})$ & $3.5-6.0$ & 6.8 & 7.6 & 8.5 & 6.8 & 7.63 & 5.8 \\
\hline Age of Flowering (month) & $7-9$ & - & - & 10 & 10 & - & - \\
\hline Fruit Size $(\mathrm{mm})$ & $4.0-6.5$ & - & - & - & - & 6.1 & 6.1 \\
\hline Fruit Weight per Spike (g) & $4.5-11.5$ & - & - & - & - & - & - \\
\hline Percentage of Perfect Fruit (\%) & $60.7-90.7$ & 64.8 & 66.1 & 66.7 & 60.4 & 82 & 61.3 \\
\hline Weight of 1000 fruit $(\mathrm{g})$ & $89.98-174.56$ & 57 & 56 & 53 & 57 & 155.2 & 118.2 \\
\hline Weight of 1000 dried seeds ( $\mathrm{g}$ ) & $27.67-52.61$ & 40.1 & 43.1 & 38 & 41.8 & 51.94 & 45.97 \\
\hline
\end{tabular}




\section{ACKNOWLEDGEMENTS}

This research was funded by Penelitian Dosen Pemula Grant 2019 from Ministry of Research, Technology, and Higher Education of the Republic of Indonesia.

\section{REFERENCES}

Bermawie N, Wahyuni S, Heryanto R, Darwati I. 2019. Morphological characteristics, yield and quality of black pepper Ciinten variety in three agro-ecological conditions. IOP Conf Ser: Earth Environ Sci 292: 012065. DOI: 10.1088/1755-1315/292/1/012065.

Bhandari H, Bhanu AN, Srivasta K, Singh M, Shreya, Hemantarajan A 2017. Assessment of genetic diversity in crop plants-an overview. Adv Plants Agric Res 7: 279-286. DOI 10.15406/apar.2017.07.00255

BPS-Statistics of Kepulauan Bangka Belitung Province. 2019. Kepulauan Bangka Belitung Province in Figures. BPS Bangka Belitung, Bangka. [Indonesian]

Carsono N. 2008. Peran pemuliaan tanaman dalam meningkatkan produksi pertanian di Indonesia. Seminar on Agricultural Sciences: Mencermati Perjalanan Revitalisasi Pertanian, Perikanan dan Kehutanan dalam Kajian Terbatas Bidang Produksi Tanaman Pangan. Tokyo. [Indonesian]

Cooper HD, Spillane C, Hodgkin T. 2001. Broadening the Genetic Base of Crop Production. CABI, Wallingford, UK

Direktorat Jenderal Kekayaan Intelektual. 2019. https://pdkiindonesia.dgip.go.id/index.php/ig/djU4ZFJia1dGS3JMejJ6Q003Szlh Zz09?q=lada\&type $=1$

Effendy, Respatijarti, Waluyo B. 2018. Genetic variability and heritability characters of yield component and yield of physalis (Physalis sp.). Jurnal Agro 5: 30-38. DOI: 10.15575/1864

Etikan I, Musa SA, Alkassim RS. 2016. Comparison of convenience sampling and purposive sampling. Am J Theor Appl Stat 5: 1-4. DOI: 10.11648/j.ajtas.20160501.11.

Goncalves RF, Silva AMS, Silva AM, Valentao P, Ferreres F, Izquiedo AG, Silva JB, Santos D, Andrade PB. 2013. Influence of taro (Colocasia esculenta L. Shott) growth conditions conditions on the phenolic composition and biological properties. Food Chem 14: 34803485 .

Ifah AA, Yuniastuti E, Parjanto. 2018. Analysis of breadfruit plant diversity (Artocarpus altilis P.) by random amplified polymorphic DNA (RAPD) in DIY. AIP Conf Proc. 2021 070004. DOI: 10.1063/1.5062802.

IPGRI. 1995. Descriptors for Black Pepper (Piper nigrum L). International Plant Genetic Resources Institute, Rome, Italy.

Kearsey MJJ, Pooni HSS. 1996. The Genetical Analysis of Quantitative Traits. Chapman \& Hall, London.

Listyati O, Hasibuan AM, Stiyono RT. 2012. Farmer preference of technology adoption of hybrid pepper that resistant to foot rot disease. Buletin Ristri 3: 125-134. DOI: 10.21082/jtidp.v3n2.2012.p125-134
Mustikarini ED, Prayoga GI, Santi R, Nurqirani Z, Saragi H. 2019. Genetic parameter contributing to lodging resistance of $F 2$ population in red rice. IOP Conf. Ser.: Earth Environ. Sci. 334 012066. DOI: 10.1088/1755-1315/334/1/012066

Panggabean MT, Amanah S, Tjitropranoto P. 2016. Persepsi petani lada terhadap diseminasi teknologi usahatani lada di Bangka Belitung. Jurnal Penyuluhan 12: 61-73. [Indonesian]

Preethy TT, Aswathy TS, Sathyan T, Dhanya MK, Murugan M. 2018. Performance, diversity analysis and character association of black pepper (Piper nigrum L.) accessions in the high altitude of Idukki Sub-district, Kerala. J Spices Aromatic Crops. 27: 17-21. DOI: 10.25081/josac.2018.v27.i1.1010

Pusat Penelitian dan Pengembangan Perkebunan. 2015. Perkembangan lada Bogor Bangka. Info Perkebunan. http://www.litbang.pertanian.go.id/info-teknologi/2376/. [Indonesian]

Pusat Perlindungan Varietas Tanaman dan Perizinan Pertanian. 2019. Pusat Perlindungan Varietas Tanaman dan Perizinan Pertanian. Kementerian Pertanian, Republik Indonesia, Jakarta. [Indonesian]

Ravindran PN. 2000. Black pepper: Piper nigrum. CRC Press.

Santi R, Aini SN, and Darmawan N. 2018. Growth and production of melon plant (Cucumis melo L) in ultisol soil with addition of liquid organic fertilizer (LOF) pineapple peel. Agrosainstek: Jurnal Ilmu dan Teknologi Pertanian 2: 31-39. DOI: 10.33019/agrosainstek.v2i1.2

Simpson MG. 2019. Plant Systematics. Academic Press, New York.

Singh M, Bisht IS, Dutta M. 2014. Broadening the Genetic Base of Grain Legumes. Springer, New York.

Srinivasan K. 2007. Black pepper and its pungent principle-piperine: a review of diverse physiological effects. Crit Rev Food Sci Nutr 47: 735-748.

Sun W, Yuan X, Liu ZJ, Lan S, Tsai WC, Zou SQ. 2019. Multivariate analysis reveals phenotypic diversity of Euscaphis japonica population. PloS One. 14 (7): e0219046. DOI: 10.1371/journal.pone.0219046

Tshilenge-Lukanda L, Nkongolo KKC, Narendrula R, Kalonji-Mbuyi A, Kizungu RV. 2012. Molecular characterization of groundnut (Arachis hypogaea L.) accessions from a gene pool: Application of gamma-ray radiations. J Plant Breed Crop Sci 4: 175-183. DOI: 10.5897/JPBCS12.049.

Wahyuno D, Manohara D, Ningsih SD, Setijono RT. 2010. Development of improved black pepper variety resistant to foot rot disease caused by Phytophthora capsici. Jurnal Litbang Pertanian 29: 86-95. DOI: 10.21082/jp3.v29n3.2010.p86-95.

Waqar-Ul-Haq, Malik MF, Rashid M, Munir MQ, Akram Z. 2008. Evaluation and estimation of heritability and genetic advancement for yield-related attributes in wheat lines. Pak J Bot 40: 1699-1702.

Yudiyanto Y, Rizali A, Munif A, Setiadi D, Qayim I. 2015. Environmental factors affecting productivity of two Indonesian varieties of black pepper (Piper nigrum L.). Agrivita J Agric Sci 36: 278-284. DOI: : 10.17503/agrivita.v36i3.456

Zulchi T, Kurniawan H, Afza H, Husni P, Agus M, Nurul A. 2016. Germplasm diversity of groundnut based on the character of morphology, result, and oil content. Jurnal Pendidikan Biologi Indonesia 2: 133-146. DOI: 10.22219/jpbi.v2i2.3466. 